\title{
A study to compare the efficacy of ormeloxifene with norethisterone and conventional oral contraceptive pills
}

\author{
Monica Chauhan $^{1 *}$, Neena Gupta ${ }^{2}$, Seema Dwivedi $^{2}$, Shaily Agarwal²
}

\begin{abstract}
${ }^{1}$ Department of Obstetrics and Gynecology, SGRR Medical College, Dehradun, Uttarakhand, India
${ }^{2}$ Department of Obstetrics and Gynecology, GSVM Medical College, Kanpur, Uttar Pradesh, India
\end{abstract}

Received: 25 July 2017

Accepted: 22 August 2017

\section{*Correspondence:}

Dr. Monica Chauhan,

E-mail: chauhanmonica290@gmail.com

Copyright: (c) the author(s), publisher and licensee Medip Academy. This is an open-access article distributed under the terms of the Creative Commons Attribution Non-Commercial License, which permits unrestricted non-commercial use, distribution, and reproduction in any medium, provided the original work is properly cited.

\begin{abstract}
Background: Dysfunctional uterine bleeding is one of the commonest conditions for which patients seek advice in gynaecological outpatient department. Objective of present study was comparative evaluation of ormeloxifene with norethisterone and conventional oral contraceptive pills in dysfunctional uterine bleeding.

Methods: This randomized study was conducted on 300 cases of dysfunctional uterine bleeding and they were distributed into three groups. group I were given ormeloxifene $60 \mathrm{mg}$ biweekly for first 12 weeks followed by $60 \mathrm{mg}$ weekly for next 12 weeks. Group II were given norethisterone $5 \mathrm{mg}$ BD from 5 th to 25 th day of cycle and group III were given oral contraceptive pills from $5^{\text {th }}$ to $25^{\text {th }}$ day of cycle.

Results: Subjective improvement was outstanding in group I in comparison to other two groups. There was also statistically significant increase in $\mathrm{Hb} \mathrm{g} / \mathrm{dl}$ and statistically significant decrease in endometrial thickness.

Conclusions: Ormeloxifene was found to be superior to both norethisterone and conventional OCPs.
\end{abstract}

Keywords: Dysfunctional uterine bleeding, Endometrial thickness, Hemoglobin

\section{INTRODUCTION}

Dysfunctional uterine bleeding is one of the commonest conditions for which patients seek advice in gynaecological outpatient department. ${ }^{1}$ It is estimated that $9 \%-30 \%$ of women of reproductive age suffer from menorrhagia. $^{2}$ The prevalence increases with age, peaking just prior to menopause. Because most cases are associated with anovulatory menstrual cycles, adolescent and perimenopausal women are particularly vulnerable.

About $20 \%$ of affected individuals are in adolescent age group and $50 \%$ of affected individuals are aged between 30-40 years. ${ }^{3}$

Dysfunctional uterine bleeding (DUB) is a type of abnormal uterine bleeding where irregular uterine bleeding occurs in the absence of recognizable pelvic pathology, general medical disease, or pregnancy. ${ }^{4,5} \mathrm{New}$ FIGO classification 2011, for abnormal uterine bleeding is PALM-COIEN (Polyp, Adenomyosis, Leiomyoma, Malignancy, Coagulopathy, Iatrogenic, Endometrial, Not classified).

In spite of current development of minimal invasive surgical approaches, the traditional hysterectomy is still the only suitable definitive therapy instituted.

In recent years, concern has been expressed about possible long-term complications of hysterectomy like premature ovarian failure.

Thus, more and more women are looking forward to an effective medical therapy. Dysfunctional uterine bleeding 
is most often the result of endocrinological dysfunction which responds well to conservative treatment.

Even though a number of treatment modalities are available, a reliable drug for management of dysfunctional uterine bleeding should meet the requirements like drug should be effective, convenient to take, cost of the drug must be low, with minimal side effects and the drug should have longest safety margins.

Ormeloxifene, chemically is trans-7 methoxy-2, 2dimethyl-3-phenyl-chroman-4-yl phenoxy ethyl pyrrolidine. It is one of the $3^{\text {rd }}$ generation Selective Estrogen Receptor Modulator. It blocks the cytosol receptor by its competitive binding over estradiol and causes asynchrony in the menstrual cycle between ovulation and the development of uterine lining. It is known as non-hormonal, non-steroidal. ${ }^{6}$

Oral contraceptives produce first proliferation and then secretary changes in the endometrium similar to that during normal cycle and thus re-establishes predictable bleeding pattern.

Progestogen decreases Estrogen receptors and increase conversion of Estradiol to less potent Estrone Sulphate. These effects produce maturation of endometrium, enhancement of stromal matrix and cessation of bleeding.

\section{METHODS}

This randomized study was conducted in Upper India Sugar Exchange Maternity Hospital, department of Obstetrics and Gynaecology, GSVM Medical College, Kanpur from January 2013 till August 2014.

\section{Inclusion criteria}

Newly diagnosed dysfunctional uterine bleeding, After removal of IUCD, Perimenopausal dysfunctional uterine bleeding.

\section{Exclusion criteria}

One who desire future pregnancy, having polycystic ovarian, disease, liver pathology, renal pathology, chronic cervicitis, tubercular patients, nursing mother in first six months, diabetes, thyroid disorder, those having hypersensitivity and autoimmune disorder.

Cases of dysfunctional uterine bleeding fulfilling the inclusion and exclusion criteria were initially selected.

Subjects those who were wiling for medical treatment were taken up for study and were randomly assigned one or the other modality of treatment.

Patients not responding to medical treatment or not wiling for medical treatment were taken up for surgery.
Patients willing for medical treatment were assigned into; Ormeloxifene (Group I), Progesterone (Group II) and Combined Oral Contraceptive Pills (Group III).

Group I received Ormeloxifene 60mg twice a week for 12 weeks followed by once a week for next 12 weeks; Group II received Norethisterone $5 \mathrm{mg}$ daily twice a day from $5^{\text {th }}$ to $25^{\text {th }}$ day for 6 cycles; Group III received MALA $\mathrm{N}$ from day $5^{\text {th }}$ to $25^{\text {th }}$ day for 6 cycles.

All patients selected for present study were studied in detail with regard to clinical history, general examination, local examination and basic investigation.

\section{RESULTS}

Present study was conducted on 300 individuals ranging from 21 to 50 years of age. Maximum number of patients were in the age group of 31 to 40 years as shown in Table 1.

Table 1: Distribution of patients according to age.

\begin{tabular}{|llll|}
\hline Age & $\begin{array}{l}\text { Group I } \\
(\mathbf{n}=111)\end{array}$ & $\begin{array}{l}\text { Group II } \\
(\mathbf{n}=114)\end{array}$ & $\begin{array}{l}\text { Group III } \\
(\mathbf{n}=117)\end{array}$ \\
\hline $21-30$ & $31(28 \%)$ & $23(20 \%)$ & $28(24 \%)$ \\
\hline $31-40$ & $57(52 \%)$ & $68(62 \%)$ & $66(56 \%)$ \\
\hline $41-50$ & $23(20 \%)$ & $23(20 \%)$ & $23(20 \%)$ \\
\hline
\end{tabular}

The various parameters to assess the subjective and clinical improvement at the end of 3 and 6 months post treatment groups showed significant improvement in all 3 groups, however ormeloxifene group showed significantly $(\mathrm{p}<0.001)$ better improvement in comparison to OCPs and norethisterone group also symptomatic relief and subjective feelings in relation to improvement of menstrual abnormalities, any desirable side effects was greater with ormeloxifene as in Table 2.

Endometrial thickness also showed reduction in all three groups but more significant $(\mathrm{p}<0.001)$ reduction was observed in ormeloxifene group as shown in Table 3.

Table 4 shows improvement in hemoglobin, marked elevation seen with ormeloxifene group and least elevation seen with norethisterone group.

\section{DISCUSSION}

In present study, maximum number of patients $(>50 \%)$ were from age group of 31-40 years and it was seen that most of the above patients were multiparous (36\%$50 \%$ )and this was most probably because multiparity may lead to alteration in hypothalmo pituitary ovarian axis. Our results were comparable to other studies that were conducted, one of the study is done by Komaram R et al. ${ }^{7}$ more than $80 \%$ of patients were persistently compliant with the treatment in ormeloxifene group while at the other end compliance was very poor $(<25 \%)$ with the treatment in MALA-N group. 
Table 2: Subjective improvement in all groups.

\begin{tabular}{|c|c|c|c|c|c|c|}
\hline & & $\begin{array}{l}\text { No } \\
\text { improvement } \\
\text { No. of PT. }\end{array}$ & $\begin{array}{l}\text { Below average } \\
\text { improvement } \\
\text { No. of PT. }\end{array}$ & $\begin{array}{l}\text { Average } \\
\text { improvement } \\
\text { No. of PT. }\end{array}$ & $\begin{array}{l}\text { Considerable } \\
\text { improvement } \\
\text { No. of PT. }\end{array}$ & $\begin{array}{l}\text { Outstanding } \\
\text { improvement } \\
\text { No. of PT. }\end{array}$ \\
\hline \multirow{3}{*}{ General health } & ORME & 4 & 8 & 12 & 34 & 42 \\
\hline & NET & 14 & 16 & 12 & 18 & 40 \\
\hline & MALA N & 20 & 19 & 22 & 21 & 18 \\
\hline \multirow{3}{*}{$\begin{array}{l}\text { Amount of } \\
\text { vaginal } \\
\text { bleeding }\end{array}$} & ORME & 11 & 2 & 15 & 16 & 56 \\
\hline & NET & 14 & 13 & 9 & 25 & 39 \\
\hline & MALA N & 25 & 23 & 20 & 12 & 20 \\
\hline \multirow{3}{*}{$\begin{array}{l}\text { Abdominal } \\
\text { pain }\end{array}$} & ORME & 8 & 9 & 21 & 13 & 49 \\
\hline & NET & 10 & 11 & 6 & 34 & 39 \\
\hline & MALA N & 8 & 32 & 28 & 15 & 17 \\
\hline \multirow{3}{*}{$\begin{array}{l}\text { Degree of } \\
\text { limitation of } \\
\text { social activity }\end{array}$} & ORME & 4 & 5 & 8 & 26 & 57 \\
\hline & NET & 7 & 13 & 13 & 19 & 48 \\
\hline & MALA N & 15 & 30 & 18 & 10 & 27 \\
\hline \multirow{3}{*}{$\begin{array}{l}\text { Effect on } \\
\text { sexual activity }\end{array}$} & ORME & 2 & 8 & 14 & 24 & 52 \\
\hline & NET & 4 & 9 & 15 & 26 & 46 \\
\hline & MALA N & 14 & 29 & 19 & 15 & 23 \\
\hline
\end{tabular}

Table 3: Comparative evaluation of improvement in endometrial thickness among all three study groups.

\begin{tabular}{|lllllll|}
\hline ET & 3 months & & & 6 months & & \\
Group & T & P value & inference & T & P value & Inference \\
\hline I Vs II & 3.66 & $<0.001$ & Sig & 3.92 & $<0.001$ & Sig \\
\hline I Vs III & 5.68 & $<0.001$ & Sig & 10.43 & $<0.001$ & Sig \\
\hline II Vs III & 1.79 & $>0.05$ & Non Sig & 6.14 & $<0.001$ & Sig \\
\hline
\end{tabular}

Tbale 4: Comparative evaluation of hemoglobin in among all three study groups.

\begin{tabular}{|lllllll|}
\hline Hb & 3 months & \multicolumn{2}{c}{$\mathbf{6}$ months } & & Inference \\
\hline Groups & T & P & Inference & t & p & \\
\hline I Vs II & 8.35 & $<0.001$ & Sig & 17.07 & $<0.001$ & Sig \\
\hline I Vs III & 14.79 & $<0.001$ & Sig & 8.51 & $<0.001$ & Sig \\
\hline II Vs III & 8.48 & $<0.001$ & Sig & 4.9 & $<0.001$ & Sig \\
\hline
\end{tabular}

Equal number of patients were distributed among the study groups randomly. The patients were questioned on a five point Likert Questionnaire so as to assess the subjective improvement during the course of treatment. Patients were questioned about general health, amount of vaginal bleeding, abdominal pain and degree of limitation of social and sexual activity and were scored on a scale of one to five. The analysis of subjective improvement showed that patients using ormeloxifene were more satisfied compared to norethisterone and combined oral contraceptive pills. This result was comparable to other studies. $^{8}$

In present study, we have made use of student paired and unpaired $\mathrm{t}$ test for statistical analysis. When statistical analysis was done of various parameters i.e. Endometrial thickness, and hemoglobin within the group the values were found to be significant as $\mathrm{p}<0.001$. When all three study groups were compared with each other using student paired t test it was found that ormeloxifene scored better in all parameters i.e. ET, and $\mathrm{Hb}$ and present results were comparable to the results of other studies. ${ }^{9-12}$

\section{CONCLUSION}

Though the results of the study are encouraging and ormeloxifene is emerging as a good option to the conventional treatment modalities available which are fraught with one or the other limiting factors, but it is not the answer to every case of DUB. Treatment needs to be individualized and patients should be offered and tried with treatment with other drugs interchanging before labeling it as failure to medical treatment and directly jumping over to more invasive procedures such as minor surgeries or hysterectomy.

Efficacy in chronic dysfunctional uterine bleeding (for years) could not be studied due to paucity of time. Longer 
study period and follow up is needed to ascertain efficacy over longer duration dysfunctional uterine bleeding.

\section{ACKNOWLEDGMENTS}

Authors wish to express my sincere gratitude towards my co-authors Dr Neena Gupta, Dr Seema Dwivedi and Dr. Shaily Agarwal.

\section{Funding: No funding sources}

Conflict of interest: None declared

Ethical approval: The study was approved by the Institutional Ethics Committee

\section{REFERENCES}

1. Edlund M, Magnusson C, Von Schoultz B. Quality of life, a Swedish survey of 2200 women with DUB. London Royal Society of Medicine Press;1994:36-7.

2. National Statistics Online (2001). Available at www.statistics.gov.uk/ census $2001 \quad / p o p$ 2001/england wales.asp.2002. Accessed on $21^{\text {st }}$ April 2002.

3. Chandra BS, Kumar SS, Shankar BT, Chandra GRS, Chandra RA, Prasad KS. Ormeloxifene a selective estrogen receptor modulator, for treatment of dysfunctional menorrhagia. J Obstet Gynecol lnd. 2004;54(1):56-59.

4. Nicholson WK, Ellison SA, Grason H, Powe NR. Patterns of ambulatory care use for gynaecological conditions: a national study. Am J Obstet Gynecol. 2001;180:523-30.
5. Konar H. Abnormal menstrual bleeding. D. C Dutta ${ }^{\text {ee }}$ S Textbook of Gynaecology. $6^{\text {th }}$ ed. New Delhi: Jaypee Brothers Medical Publishers;2014:180.

6. Osborne CK, Zhao H, Fuqua SA. Selective estrogen receptor modulators: structure, function, and clinical use. J Clin Oncol. 2000;18(17):3172-86.

7. Ravibabu K, Palla J, Chintada GS. A study of efficacy of ormeloxifene in the pharmacological management of dysfunctional uterine bleeding. JCDR. 2013;7(11):2534-6.

8. Dhananjay BS, Nanda SK. The role of sevista in the management of dysfunctional uterine bleeding. J Clin Diagn Res. 2013;7(1):132-4.

9. Falcone T, Desjardins C, Borque J. Dysfunctional uterine bleeding in adolescents. J Reprod Med. 1994;39(10):761.

10. Chitrangada, Singh SK, Nag S. A double blinded randomized controlled trial to compare Ormeloxifene and Norethisterone in the treatment of dysfunctional uterine bleeding. IOSR-JDMS. 2014;13(1):52-56.

11. Bhattacharya TK. Efficacy of SERMs; ormeloxifene in DUB. JSAFOG. 2010;2(3):207-211.

12. Kriplani A, Kulshreshtha. Efficacy and safety of ormeloxifene in management of uterine bleeding. Chapter 30, $6^{\text {th }}$ ed. London, Butterworths;2001:560580 .

Cite this article as: Chauhan M, Gupta N, Dwivedi S, Agarwal S. A study to compare the efficacy of ormeloxifene with norethisterone and conventional oral contraceptive pills. Int J Reprod Contracept Obstet Gynecol 2017;6:4469-72. 